\title{
Goliath grouper Epinephelus itajara oral history, use, and conservation status in the Mexican Caribbean and Campeche Bank
}

\author{
Arturo Bravo-Calderon ${ }^{1,2}$, Andrea Saenz-Arroyo ${ }^{2,3, *}$, \\ Stuart Fulton ${ }^{1}$, Alejandro Espinoza-Tenorio ${ }^{2}$, Eloy Sosa-Cordero ${ }^{2}$ \\ ${ }^{1}$ Comunidad y Biodiversidad A.C. Calle del Peruano, Lomas de Miramar, Guaymas, 85448 Sonora, Mexico \\ ${ }^{2}$ El Colegio de la Frontera Sur. Periferico Sur, Maria Auxiliadora, San Cristobal de Las Casas, 29290 Chiapas, Mexico \\ ${ }^{3}$ Centro de Ciencias de la Complejidad (C3), Universidad Nacional Autónoma de México, \\ Circuito, Mario de La Cueva 20, Insurgentes Cuicuilco, Coyoacán, Ciudad de México, Mexico
}

\begin{abstract}
The Atlantic goliath grouper Epinephelus itajara is highly vulnerable to overfishing, yet little is known of its population status in Campeche Bank (southern Gulf of Mexico) and the Mexican Caribbean. By reviewing landings records, historical literature, and the local ecological knowledge of fishers, we documented historical practices, uses, and changes in the abundance and distribution of the goliath grouper in these regions. In both the Mexican Caribbean and Campeche Bank, goliath grouper populations were notably impacted by commercial fishing activities in the 1970s and 1980s. The catches during this period could only be sustained for a few years, after which the fishery collapsed. Our results from Campeche Bank indicate that populations persist in an area currently occupied by oil platforms. In the Mexican Caribbean, the extirpation of the goliath grouper may be close at hand, with local exceptions like that of Chetumal Bay. The results of our study indicate that the local goliath grouper populations are in critical danger of extinction, which must be taken into account during the next IUCN Red List regional assessment. In addition, the goliath grouper should be included in the Mexican list for endangered species (NOM-059-SEMARNAT).
\end{abstract}

KEY WORDS: Endangered species $\cdot$ Historical ecology $\cdot$ Home range $\cdot$ Local ecological knowledge

\section{INTRODUCTION}

The Atlantic goliath grouper Epinephelus itajara (hereinafter goliath grouper) is the largest member of the Epinephelidae family. In the Atlantic, the distribution of the goliath grouper spans the tropical and subtropical coasts of North and South America, from the northeastern coast of the Florida peninsula to Santa Catalina in Brazil (Craig et al. 2009), and the coasts of Africa, from Senegal to Angola (Craig et al. 2009). The goliath grouper possesses many characteristics that make it vulnerable to overfishing, including high longevity, late maturation, site fidelity,

${ }^{*}$ Corresponding author: msaenz@ecosur.mx aggregative spawning, and a lack of fear of humans (Bullock et al. 1992, Sadovy \& Eklund 1999).

Juveniles have been associated with the presence of overhangs and complex structures that provide shelter, particularly those in mangroves, which are fundamental to their development (Frias-Torres 2006, Koenig et al. 2007). Like juveniles, adults have also been associated with complex structures, including those that are artificial (Giglio et al. 2014a, Collins et al. 2015). However, the presence of large adults (>150 cm total length) in shallow water and sub-adults in areas away from mangroves demonstrate that movement and site fidelity may not neces-

() The authors 2021. Open Access under Creative Commons by Attribution Licence. Use, distribution and reproduction are unrestricted. Authors and original publication must be credited. 
sarily influence development in this species (Koenig et al. 2007, Collins \& Barbieri 2010, Collins et al. 2015, Zapelini et al. 2017). It has also been suggested that adult migrations among shallow areas and mangroves constitute a feeding strategy (Zapelini et al. 2017), although it has also been proposed that goliath groupers can modify their feeding habits based on prey activity and availability (Collins \& Motta 2017).

Throughout their distribution, goliath grouper populations have been in decline since the 1950s, with the exception of populations in the southeastern USA. In this region, the goliath grouper is no longer at risk of overfishing given the moratorium established in 1990 (Koenig et al. 2011, SEDAR47 2016). The decline in goliath grouper abundance is mainly the result of spearfishing and fishing in spawning aggregation sites, in addition to a loss of mangrove coverage (Sadovy \& Eklund 1999, Giglio et al. 2017, Bertoncini et al. 2018). In 2011, the goliath grouper was subjected to its first global evaluation by the IUCN, in which it was categorized as Critically Endangered. However, the goliath grouper was recently reclassified as Vulnerable (Bertoncini et al. 2018) due to the recovery of the population in the southeastern USA. This re-categorization recognizes that populations may be subject to overfishing in some regions and not others, as evidenced by a lack of recovery of the populations in the tropical and subtropical Atlantic. In Brazil, for example, goliath grouper fishing has been prohibited since 2002 . However, from 2003-2011, landings due to poaching were estimated to be $\sim 400 \mathrm{t} \mathrm{yr}^{-1}$ in Brazil, although the actual values were probably much higher (Giglio et al. 2014b). In the Gulf of Mexico, the last regional assessment of this species listed the goliath grouper as Endangered, primarily due to non-sustainable management practices that have been implemented without species-specific landings data (EspinosaPerez et al. 2015).

The limited information available on the goliath grouper has prevented appropriate quantitative assessments from being conducted in populations throughout its distribution. Recovery of the species is further confounded by the fact that (1) effective conservation measures for this species are lacking in most countries except the USA; (2) marine reserves are not able to fully protect individuals migrating among spawning aggregation sites; and (3) illegal fishing has not been reduced due to inadequate enforcement of established guidelines and laws. Outside of the USA and Brazil, a lack of information on this species has also prevented stock assessments from being completed (Aguilar-Perera et al. 2009).
This lack of information has prevented a determination of an IUCN threat category at a global level for this species and has also impeded the identification of potential threats during each life history stage.

There is thus a need to generate historical information on the goliath grouper in sites throughout its historical distribution to establish baselines and benchmarks that reflect the original biomass of this species (Sáenz-Arroyo et al. 2006, McClenachan 2009, McClenachan et al. 2012). This is particularly important when conventional methods for assessing at-risk species are not applicable (Rhodes \& Graham 2009). In Brazil, the local ecological knowledge (LEK) of fishers has contributed to the development of a better understanding of goliath grouper reproduction, feeding, and behavior (Gerhardinger et al. 2006). Fisher LEK has also helped generate information on spawning aggregation sites (Gerhardinger et al. 2009), the impacts of some fishing gears (Giglio et al. 2017), and the effectiveness of certain conservation strategies (Zapelini et al. 2017).

In Mexico, few studies have documented or explored the historical fishing of this reef giant. In fact, only one study has suggested the presence of a possible spawning aggregation site to the north of the Yucatan Peninsula, in which significant fishing mortality was reported in the 1970s that was closely linked to the lobster fishery (Aguilar-Perera et al. 2009). In the Mexican Caribbean, a second study reported that fishers in the late 1950s in northern Belize (then British Honduras) knew of a goliath grouper aggregation site in Chetumal Bay (Craig 1966). In this area, LEK indicates that most of the fishers interviewed at the turn of the millennium were already catching 1 goliath grouper per year (García-Téllez 2002). This thesis reported that although some fishers remembered seeing goliath grouper aggregations long ago, most agreed that their abundance had notably decreased.

In this paper, we provide a historical outline of the changes in abundance and distribution of the goliath grouper in the Mexican Caribbean and Campeche Bank, 2 important fishing zones located around the Yucatan Peninsula, by analyzing catch records, historical literature, and the LEK of fishers. In particular, we aimed to develop baselines for the degree of exploitation and historical abundance of the goliath grouper in these 2 zones. Campeche Bank is located in the southern Gulf of Mexico, which is an important fishing area. In the 1970s, Campeche Bank became the main oil extraction zone in Mexico (Santiago \& Baro 1992, García-Cuéllar et al. 2004). The second largest coral barrier reef in the world is found in the 
Mexican Caribbean, which has been the subject of accelerated tourism development since the 1970s. The findings of the present study will serve to generate an improved understanding of the conservation status of this threatened fish in 2 data-poor regions.

\section{MATERIALS AND METHODS}

To assess the past importance of the goliath grouper fishery and its conservation status in the Mexican Caribbean and Campeche Bank with regard to its history of exploitation and past abundance, we followed the methodology proposed for a severely depleted grouper fishery in the Gulf of California (Sáenz-Arroyo et al. 2005), which consisted of comparing information from grey literature sources, research archives, official landings data, and LEK of fishers.

\subsection{Historical literature and fishing data}

We visited public libraries and historical archives in the Yucatan Peninsula and neighboring regions to collect information on fishing in the region. In the Caribbean, we visited the General Archive of the State of Quintana Roo and its library as well as the Santiago Pacheco Cruz library of the University of Quintana Roo. In the Gulf of Mexico, we visited the Historical and Photographic Archive of Tabasco, the General Archive of the State of Campeche, the Municipal Archive of Campeche, the José María Pino Suárez public library, and the José Martí library of the Juárez Autonomous University of Tabasco. We consulted books and official documents from these sources that described both general economic activities and particular fishing activities, following the methods that are widely used in historical ecology (Egan \& Howell 2001).

Historical fishing data were collected from sparse reports on fishing activities. Although these reports did not allow for the creation of a long-term database, they allowed for a suitable baseline to be created that could be contrasted with recent data. Data from 1980 to the present were obtained from the National Commission for Fisheries and Aquaculture (CONAPESCA; https://www.conapesca.gob.mx/wb/ cona/estadisticas_de_produccion_pesquera) and from the regional offices of each of the aforementioned states. With the information from grey literature sources and historical reports, we built a time series of the catches for both regions.

\subsection{LEK of fishers}

In late 2017, we conducted 69 interviews with fishers, SCUBA diving instructors, and tourism service providers from Tulum and Punta Allen in the state of Quintana Roo (Fig. 1). In addition, in 2019, we interviewed 7 retired fishers from Chetumal and Calderitas. Of the 76 people interviewed, $21 \%$ were over the age of $60,31.6 \%$ were $40-60 \mathrm{yr}$ old, and $47.4 \%$ were under 40 (only fishers who were at least $18 \mathrm{yr}$ old were interviewed). In 2019, we also interviewed 54 fishers from Campeche Bank, of whom $46.3 \%$ were over 60 yr old, $40.7 \%$ were between 40 and 60 yr old, and $13 \%$ were under 40 . These fishers were residents of the states of Tabasco (from Puerto Ceiba to San Pedro) and Campeche (from Nuevo Campechito to Isla Aguada; Fig. 1). To identify respondents, we intercepted fishers at their landing ports and used snowball sampling to ask the initial respondents to recommend fishers who had experience fishing goliath grouper or other finfish species and we interviewed all these fishers until the names were repeated in interviews (Babbie 2010).

All interviews were conducted in homes and landing sites (see the Appendix for the full questionnaire). Prior to each interview, we clearly explained the objective of our research, and informed consent was obtained from all interviewees. We included questions to assess changes in species abundance by asking fishers to remember their best fishing day (determined by the largest number of fish caught in a single day), the largest goliath grouper they ever caught, and the years in which these events occurred (Sáenz-Arroyo et al. 2005). In order to minimize the possibility of species misidentification, we provided fishers with color photos of the goliath groupers present in the region. We also considered important events, such as catching or observing more than 5 goliath groupers on the same day or in the same place, when collecting information. We also recorded the type of bait used. Goliath grouper juveniles less than $30 \mathrm{~kg}$ were included in the analyses.

The largest number of fish and the largest goliath grouper ever caught by the fishers helped us to reconstruct a time series (see Fig. 6). This information, together with the descriptions found in historical documents and fisher LEK regarding past goliath grouper abundance, was used to reconstruct a coherent history of the exploitation of this species and determine its state of conservation in both regions (Fogerty 2001, Sáenz-Arroyo et al. 2005). In this sense, LEK and historical materials were used as complementary sources of information to reconstruct 


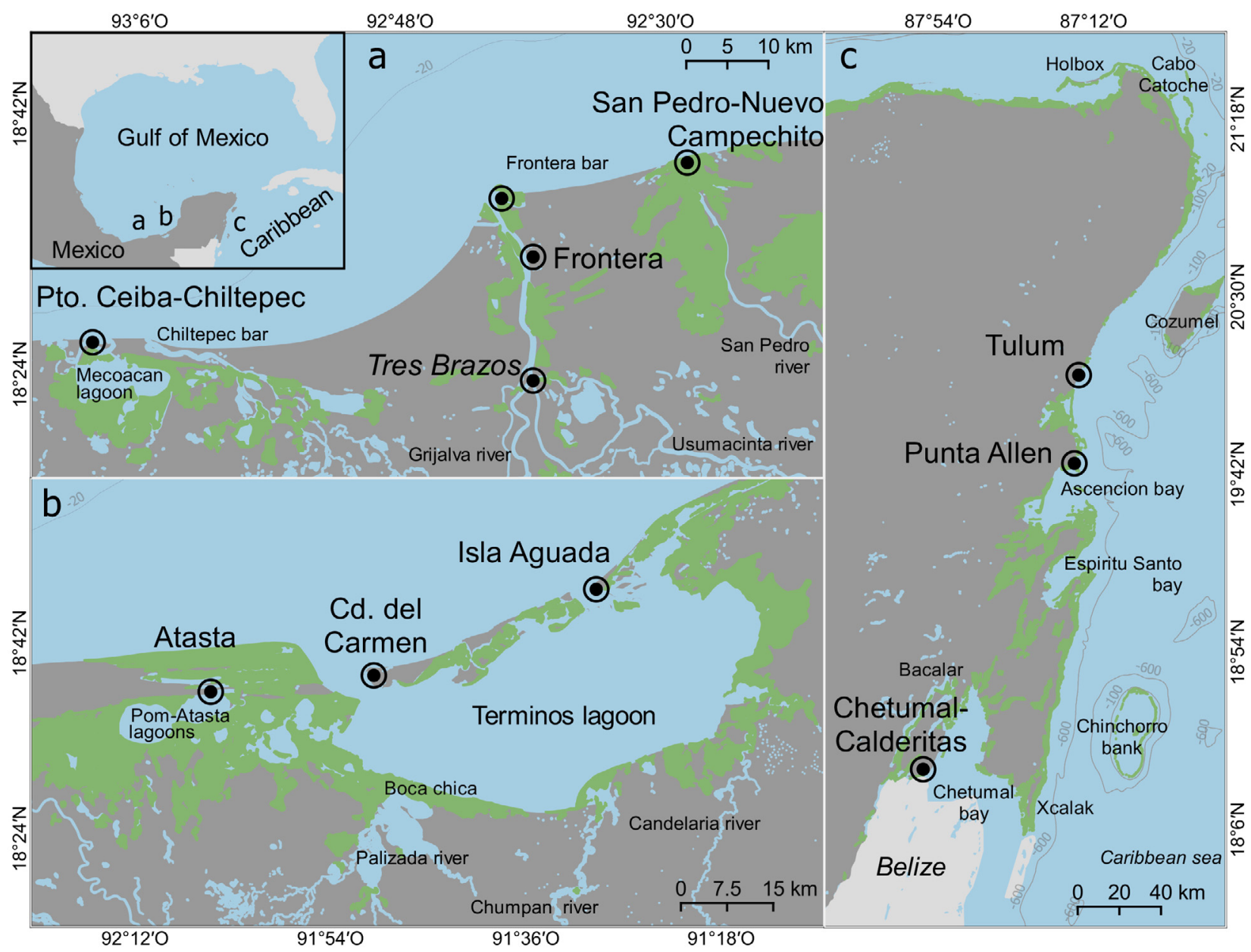

Fig. 1. Study area and locations of the fishers interviewed in this study. Green areas: mangrove coverage (INEGI 2017); (a) and (b) are located in the states of Tabasco and Campeche, respectively (the San Pedro river serves as the border), in the southern Gulf of Mexico; (c) is located in the state of Quintana Roo in the Mexican Caribbean

the exploitation history of a species for which fishing or ecological statistics are absent.

\section{RESULTS}

\subsection{History of goliath grouper fishing in Campeche Bank and the Mexican Caribbean}

Ichthyo-archaeological remains show that the goliath grouper was captured by the Maya for more than 1500 yr (Jimenez-Cano 2017) during the Classic period. Bone materials from the Classic period of the Maya (250-750 AD) show goliath groupers between 1-2 $\mathrm{m}$ in length that were probably caught in lagoons and other coastal water bodies with simple but effective fishing technologies and consumed locally (Gotz 2012, Jimenez-Cano \& Sierra-Sosa 2018).

During the $19^{\text {th }}$ century, commercial and industrial fishing in the Yucatan Peninsula targeted turtles
(Cheloniidae), manatees Trichechus manatus, monk seals Neomonachus tropicali (extinct in 1952), and sponges Hippospongia spp. and Spongia spp. (Dachary \& Arnaiz Burne 1986, McClenachan \& Cooper 2008, Rubio-Cisneros et al. 2019). Fishing has been conducted by locals and a notable number of foreigners. The first foreigners were the English who came from Belize (British Honduras) and the Spanish who came from Cuba. At the start of the $20^{\text {th }}$ century, both Cubans and Americans came to fish in the Yucatan Peninsula (Dachary \& Arnaiz Burne 1986). Although some important local fisheries were documented during the $19^{\text {th }}$ century, such as those targeting sharks in Campeche (Morelet \& Squier 1871), it was during the mid- $20^{\text {th }}$ century that fishing cooperatives began to usher in a new era of commercial fishing (Galindo-Aranda 1967, Direccion-de-Promocion-Economica-e-Industrial-del-Estado 1970, Dachary \& Arnaiz Burne 1986, Tello-Domínguez 1988). 
By this time, fishing activities were well-rooted in the lives of the inhabitants of the Yucatan Peninsula, and Campeche was reported to have the highest per capita consumption of fish in the country (Peña \& Ibarra 1942). Although the number of inhabitants in the Mexican Caribbean was negligible compared to that of Campeche Bank (0.37 inhabitants $\mathrm{km}^{-2}$ in Quintana Roo and 4.92 inhabitants $\mathrm{km}^{-2}$ in Tabasco and Campeche; INEGI 1943), fish constituted an important source of protein in the Mexican Caribbean, as the region lacked terrestrial transportation and communication routes (Dachary \& Arnaiz Burne 1986). Economic activities associated with the exploitation of trees to extract chewing gum (e.g. Manilkara zapote) and precious woods (particularly mahogany and cedar), along with the cultivation of banana and coconut crops, played an accidental role in the development of fisheries. These industries were the economic pillars of the region in the early $20^{\text {th }}$ century, and each followed the typical cycles of prosperity and collapse due to overexploitation, fluctuations in demand, variations in international prices, pestilence, and hurricane damage (Tudela 1989).

Since the 1920s, the goliath grouper has been mentioned in the literature as a commercial species in both study regions (Figs. 2 \& 3; Aguirre 1925, Ferrer et al. 1928). Like other commercial species, the increase in goliath grouper landings was closely related to governmental programs aimed at promoting fisheries. In this sense, the shrimp and lobster fisheries

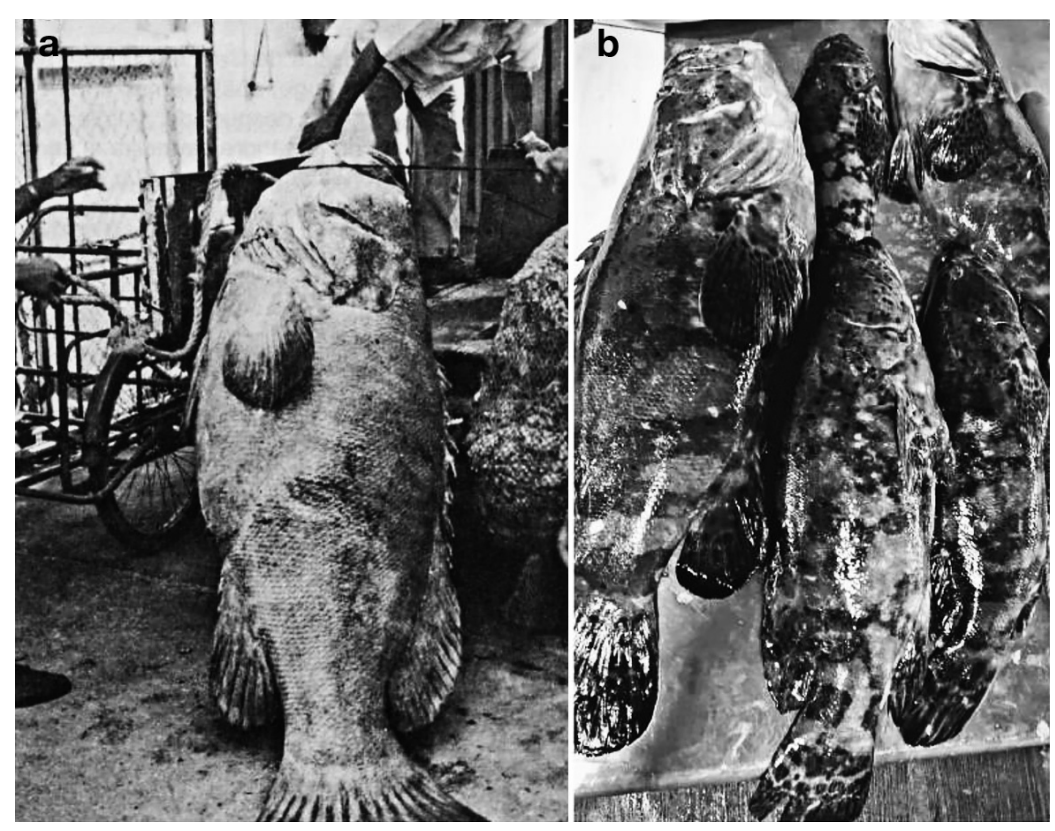

Fig. 2. Goliath groupers in Ciudad del Carmen. (a) Large individual transported by truck in the 1960s (photo by Oscar Alamina-Sosa; Caldera-Noriega 2016); (b) juveniles for sale in the market in April 2017 (photo by A. Sáenz-Arroyo) played very important roles in promoting other less valuable fisheries, such as those of finfish (Fig. 3).

The resulting labor surplus from the collapse of these traditional economic activities coupled with the LEK of traditional subsistence fishers was seized upon by the Mexican government to promote the modernization of fishing facilities and equipment, which led to the decentralization of the highland population through a federal fishing and port development program in the early 1950s called the 'March to the Sea' (Martinez-Martinez \& Gonzalez-Laxe 2016). These factors laid the foundation for a commercial fishing industry based on the export of highdemand, high-value species to the US market, particularly shrimp and oysters from the southern Gulf of Mexico, groupers from the northern region of the Yucatan Peninsula, and lobster and conch from the Mexican Caribbean (Carranza 1957).

In Campeche Bank, the shrimp industry quickly consolidated itself as the most important economic activity in the region in the mid-20 ${ }^{\text {th }}$ century (GalindoAranda 1967), with Ciudad del Carmen acting as the primary port (which would later become historic and iconic) for this fishery in the Gulf of Mexico (Fig. 3). In Frontera, a port of historical importance that was displaced due to the establishment of terrestrial communication and transportation routes, statements found in local publications illustrate how fishing became the main economic activity in the area (e.g. 'Fishing is the immediate salvation'; Pérez-Chan 1970). In the 1980s, the largest number of fishers in Tabasco was found in Frontera, which contained around $80 \%$ of the shrimp fleet and the majority of the mediumscale fleets in the state (Alcalá-Moya 1986, Tello-Domínguez 1988).

In the rest of Tabasco, the facilities provided by the government to encourage commercial fishing were used mainly by fishers who had emigrated from the state of Veracruz during the mid-1970s, as the fishing banks in Veracruz were overexploited by that time. As native fishers with strong ties to rivers and lagoons, these individuals were reluctant to head into deeper waters and found opportunities by means of governmental incentives to develop commercial fisheries in Campeche (Alcalá-Moya 1986). By then, oysters, which were cultivated and captured in lagoons, constituted the most important fishing 


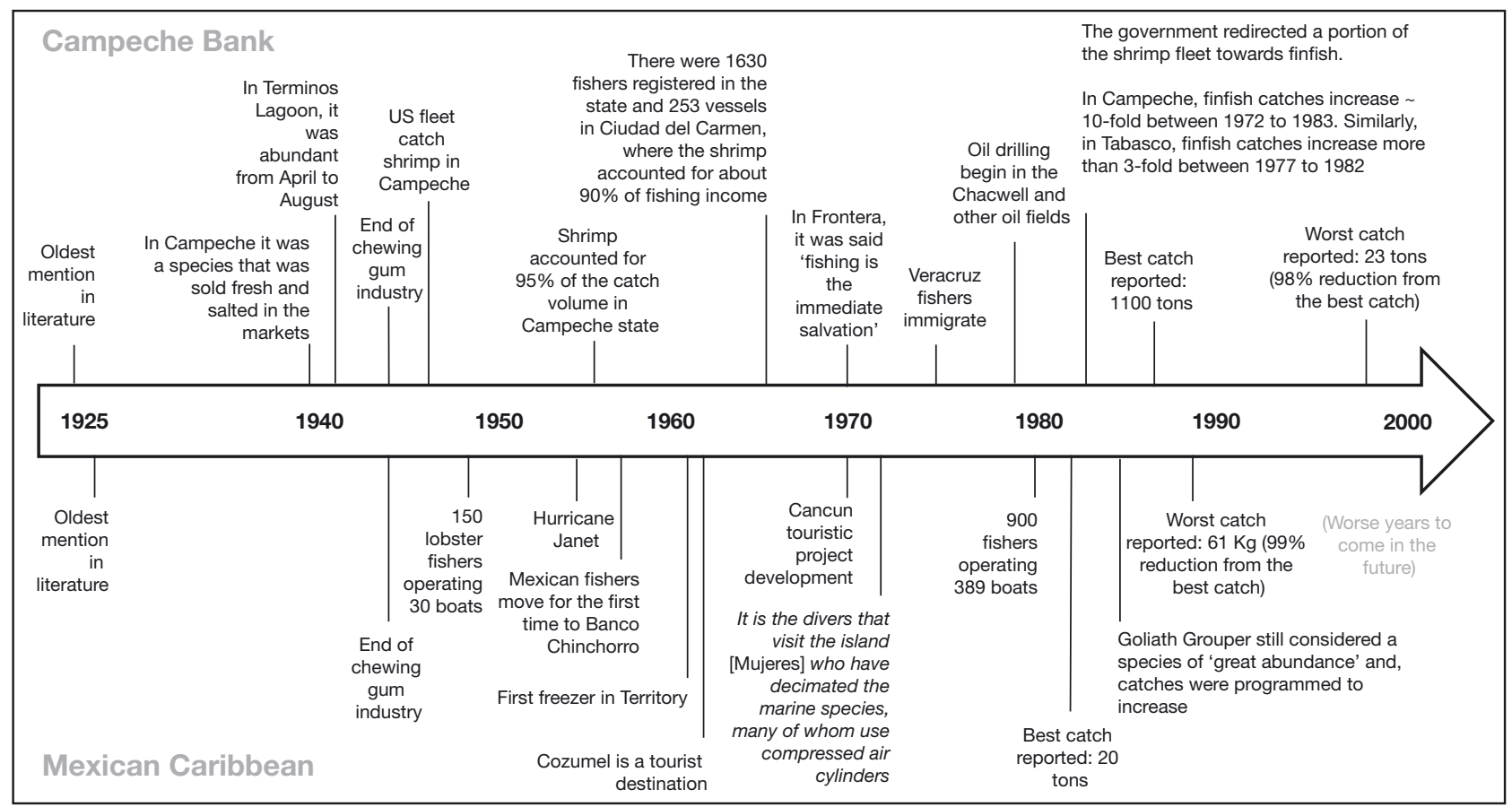

Fig. 3. Timeline of the most important historical events that triggered the exploitation of fishery resources and the collapse of the goliath grouper fishery in Campeche Bank and the Mexican Caribbean. Compiled from Aguirre (1925), Ferrer et al. (1928), Ayuntamiento-de-Campeche (1940), Peña \& Ibarra (1942), Osorio-Tafall (1948), Carranza (1957), Solís-Ramírez (1966), Galindo-Aranda (1967), Direccion-de-Promocion-Economica-e-Industrial-del-Estado (1970), Pérez-Chan (1970), Bravo (1972), Delegación-de-Pesca (1985), Alcalá-Moya (1986), Dachary \& Arnaiz Burne (1986), Tello-Domínguez (1988), Collins et al. (2015), Ramírez-Rodríguez (2015)

resource, although all of the oyster fishers also fished finfish for their own consumption (Alcalá-Moya 1986).

During the 1980s, the government redirected a portion of the shrimp fleet towards finfish, which significantly increased the fishing effort across a range of species. The maximum goliath grouper catches reported in official documents for Campeche Bank coincide with this period (Fig. 4). By then, the Mexican oil industry had begun its glory days in the Gulf of Mexico, after the Chac well was drilled in one of the most productive offshore oil fields ever discovered (Santiago \& Baro 1992).

Fig. 4. Goliath grouper catch records for the states of Tabasco and Campeche in Campeche Bank (CB) and Quintana Roo in the Mexican Caribbean (MC). White circles: catches from Campeche and Xcalak in the $\mathrm{CB}$ and $\mathrm{MC}$, respectively. Connecting lines indicate that no gaps in data were present between years. Data after 1999 were provided by the state and fisheries offices, with the remaining data coming from fisheries yearbooks or previously published sources (SolísRamírez 1966, Galindo-Aranda 1967, Fuentes 1977, Dachary \& Arnaiz Burne 1986)

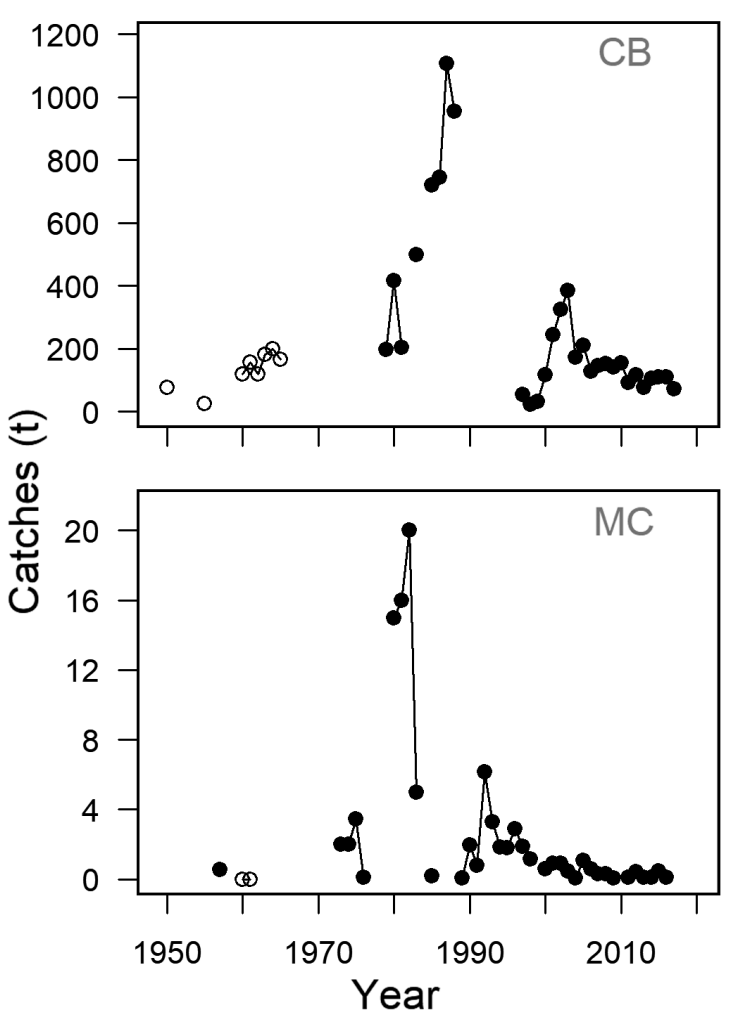


In Campeche Bank, goliath grouper catches were $\sim 400$ t on average in the early 1980s, with the landings peaking at $\sim 1100 \mathrm{t}$ in 1987 . During this decade, the number of smaller vessels dedicated to finfish fishing more than tripled. The fishers that settled around Terminos Lagoon operated $\sim 400$ boats and targeted the goliath grouper and other species (Smith et al. 1988). In 1998, goliath grouper landings constituted only about $2 \%$ of all landings. Over the past 2 decades, landing records show that more than half of the goliath grouper landings came from fishers who lived in the areas surrounding Terminos Lagoon (i.e. Atasta, Ciudad del Carmen, and Isla Aguada), whereas $34 \%$ of landings came from fishers who lived in the downriver sections of the Grijalva and Usumacinta Rivers near Frontera. The remaining portion of the grouper landings was attributed to fishers from the area of the Mecoacan Lagoon (i.e. Chiltepec, El Bellote, and Puerto Ceiba; Fig. 1). Since 2004, landings have decreased, and goliath grouper catches are rare (Fig. 4).

In the Mexican Caribbean during the mid-20 ${ }^{\text {th }}$ century, Bibiano F. Osorio Tafall, a respected Spanish scientist exiled in Mexico who was in charge of determining the needs of the incipient fishing industry, reported that the goliath grouper was an abundant species with an average weight of $56.6 \mathrm{~kg}$, although individuals weighing up to $317.5 \mathrm{~kg}$ were occasionally caught (Osorio-Tafall 1948). A great abundance of goliath groupers was recorded with underwater cameras by some of the early explorers of the region, such as Ramon Bravo. In the early 1970s, sites known for high goliath grouper abundance, such as the 'Goliath Grouper Rocks' located near Cabo Catoche (Fig. 1), were recorded by Ramon Bravo (Bravo 1974).

Historical documents and grey literature sources highlight an increased use of spearguns and semiautonomous diving equipment, both by lobster fishers and recreational fishers, as the principal reason behind the overexploitation of the goliath grouper (Bravo 1972, 1974, Aguilar-Salazar 1999, MarínGuardado 2000, Rubio-Cisneros et al. 2019) given that goliath groupers and lobsters share the same habitats (i.e. caves and reefs). The fishing activity in this area increased 6-fold from 1950-1989, with most fishers targeting lobster and finfish (Fig. 3). According to official catch records, peak goliath grouper yields coincided with the start of the 1980s (Fig. 4). During this time, goliath grouper catches were 10fold higher than those in the 1970s and 15-fold higher than those in the 1990s and thereafter.

The development of tourism in Cancun in Quintana Roo created an unprecedented demand for fish. After
1982, the year with the highest recorded goliath grouper landings, this species was considered to be highly abundant, and fishing officers planned to increase catches to 33 t by 1988 (Delegación-de-Pesca 1985), a goal which was never achieved. Twelve years after the highest landings were reported, the catch was found to be 10-fold lower (Fig. 4). This low value was $<10 \%$ of the catch reported when the demand for fish first began in this region, reflecting a classic example of boom-and-bust exploitation. After this period of abundance, the fishery never recovered, and in the last decade for which data are available (2000-2010), official landings records only included one pair of goliath groupers $\left(\right.$ median $=216.5 \mathrm{~kg} \mathrm{yr}^{-1}$ ). Moreover, in 2010, the species was not registered at all.

\subsection{LEK of the goliath grouper}

Both in Campeche Bank and the Mexican Caribbean, the current outlook for the goliath grouper is very different from that of a few decades ago. A shifting baseline syndrome among the different generations working in the area is clearly present (SáenzArroyo et al. 2005). Of the fishers interviewed in the Gulf of Mexico, $17 \%$ have never fished a goliath grouper, and $9 \%$ of those who have done so have only caught immature individuals (<30 kg).

Young fishers (<40 yr old) from this region believe that the abundance of the goliath grouper has not changed (Fig. 5). In Campeche Bank, middle-aged fishers have noticed a decrease in abundance, and this trend is more marked among older fishers (>60 yr old). Between the older fishers and those under 40, an important difference can be seen between their perceptions with regard to the reduction of goliath grouper abundance in lagoons and rivers, particularly the absence of adult individuals (Table 1).

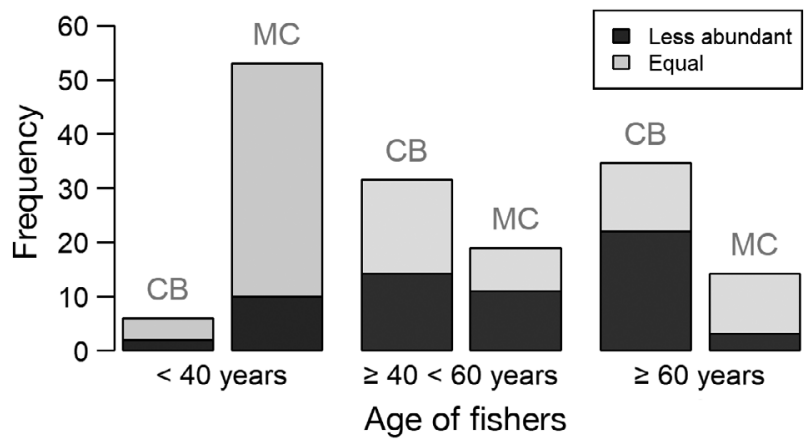

Fig. 5. Fisher perceptions of goliath grouper abundance in Campeche Bank (CB) and the Mexican Caribbean (MC). Less abundant and equally abundant are with respect to the present day 
Table 1. Local ecological knowledge of fishers in Campeche Bank on the past abundance and distribution of the goliath grouper Epinephelus itajara

\begin{abstract}
Fisher age and residence
Past abundance

84 yr old fisher from Isla Aguada

84 yr old fisher from Isla Aguada

62 yr old fisher from Frontera

61 yr old fisher from Atasta

60 yr old fisher from Frontera

52 yr old fisher from Tres Brazos

'We salted it [the goliath grouper]. It was jerked by us. The steak and the jerky were called bacalao ${ }^{\mathrm{a}} \ldots$... In the boat, the catch was taken to Veracruz and from there to Mexico City ...'

'Then, the divers started taking advantage, [with] spear guns, explosive tips, cartridges, [and] cartridges. Because of that, all is gone ... all fishing ended because of it ... .'

'... in this part of the windward side of Isla Aguada, we could fill our canoes with goliath groupers! You know, the water was so clear that you could see the goliath groupers [from the boat]. I grabbed a goliath grouper ... but look, they were big fish! And the rock where I fished them was called the 6 . In 2 days, we filled the canoe, we came back with one ton of goliath groupers...'

'They only took the fillet from the big goliath groupers, the cheek, and the bones Bam! Into the water. There were loads! Getting a goliath grouper that big now is hard.'

'Yes, here yes. You know the goliath grouper in the past ... I'll tell you when we went fishing and my dad was still alive, we used to catch an enormous quantity of goliath groupers! They use to come in this season, between April and May, when the squalls came - we could catch loads! Small sharks used to come into the lagoons you know; we'd catch them with caliche ${ }^{\mathrm{b}}$, as we called it.'

'I was in primary school ... [One day] I was at school, and the [shrimp] fleet came, and they laid out the goliath groupers on the dock, just like that, stretched out. There were all kinds of sizes: 80, 100, $200 \mathrm{~kg}$. Big goliath groupers, and they only took the meat, leaving the bone, the head, and everything else. Now they don't leave anything. A kilogram of goliath grouper costs 80 pesos in the market now [...].'

'In Tres Brazos, we fished there, where the 3 rivers [met]. We made our camps on that side. On the other side of the river, there are [now] some little houses that did not used to be there. We used to camp there to catch goliath groupers and sharks.'
\end{abstract}

Present abundance

62 yr old fisher from Puerto Ceiba

56 yr old fisher from Chiltepec

24 yr old fisher from Puerto Ceiba

${ }^{a}$ Bacalao is the Spanish word for cod

bLocal variety of a gill net. In the region, caliches were originally manufactured with sisal fiber and other local materials and were traditionally used to catch juvenile sharks
'Yes, they got rarer, due to the use of explosives. They were using a lot of explosives. This fish was in areas where it could [find] refuge; for example, in the ducts, it could find refuge there. Then, when the diving started with explosives, the animal started to migrate, to go. We threw hooks and we'd get one or 2 of them, big ones ...'

'Now, even in the shipwrecks, there isn't anything; they finished it all. In this area with the buoy, where the petrol tankers would come, in front of Dos Bocas, in that area, there was red snapper ... and the goliath groupers used to float on the long-lines because of how big they were.'

'Here, here in the lagoon there are some, but it is rare. If you see one it is rare. In the past, they say that there were lots of them. They say that when they came to fish oyster, they caught them with a sack, putting them inside.' 
Table 2. Comparisons of the best catch (no. of fish $\mathrm{d}^{-1}$ ) ever remembered and the largest fish ever caught according to fishers of different age classes. In Campeche Bank, significant differences $(p<0.05)$ were found with regard to the largest fish ever caught between young ( $<40 \mathrm{yr}$ ) and middle-aged (40-60 yr; $\mathrm{p} \geq 0.0003751)$ fishers and between young and old fishers ( $\geq 60 \mathrm{yr} ;$ $\mathrm{p} \geq 0.007466$ ). In the Caribbean, significant differences were found with regard to the best catch ever remembered between old and middle-aged fishers ( $p \geq 0.005226)$, the largest fish ever caught between young and middle-aged fishers ( $p \geq 0.04338$ ), and between middle-aged fishers and old fishers ( $p \geq 0.002825)$. Other comparisons were not significant

\begin{tabular}{|c|c|c|c|c|c|c|c|}
\hline \multirow[t]{2}{*}{ Region } & \multirow{2}{*}{$\begin{array}{l}\text { Fisher } \\
\text { age }\end{array}$} & \multicolumn{3}{|c|}{ - Best catch ever -} & \multicolumn{3}{|c|}{ —Largest fish ever caught —ـ } \\
\hline & & $\begin{array}{l}\text { Fishers } \\
\text { (n) }\end{array}$ & $\begin{array}{l}\text { Max. } \\
\text { (No.) }\end{array}$ & $\begin{array}{c}\text { Mean }( \pm \mathrm{SD}) \\
(\text { No. })\end{array}$ & $\begin{array}{l}\text { Fishers } \\
\text { (n) }\end{array}$ & $\begin{array}{c}\text { Max. } \\
(\mathrm{kg})\end{array}$ & $\begin{array}{c}\text { Mean }( \pm \mathrm{SD}) \\
(\mathrm{kg})\end{array}$ \\
\hline $\begin{array}{l}\text { Mexican Caribbean } \\
\text { (best catch reported in 1982) }\end{array}$ & $\begin{array}{l}>60 \mathrm{yr} \\
40-59 \mathrm{yr} \\
<40 \mathrm{yr}\end{array}$ & $\begin{array}{c}5 \\
12 \\
59\end{array}$ & $\begin{array}{c}11 \\
6 \\
7\end{array}$ & $\begin{array}{c}5.6 \pm 3.5 \\
2.3 \pm 2 \\
1.4 \pm 1.4\end{array}$ & $\begin{array}{c}8 \\
12 \\
55\end{array}$ & $\begin{array}{l}300 \\
200 \\
178\end{array}$ & $\begin{array}{c}164.6 \pm 70.4 \\
93.9 \pm 60 \\
57.6 \pm 47.6\end{array}$ \\
\hline $\begin{array}{l}\text { Campeche Bank (all data) } \\
\text { (best catch reported in 1987) }\end{array}$ & $\begin{array}{l}>60 \mathrm{yr} \\
40-59 \mathrm{yr} \\
<40 \mathrm{yr}\end{array}$ & $\begin{array}{c}25 \\
21 \\
5\end{array}$ & $\begin{array}{c}30 \\
13 \\
4\end{array}$ & $\begin{array}{c}7 \pm 8.6 \\
3.4 \pm 3.8 \\
2 \pm 1.2\end{array}$ & $\begin{array}{c}22 \\
18 \\
7\end{array}$ & $\begin{array}{c}300 \\
300 \\
86\end{array}$ & $\begin{array}{c}128.5 \pm 92.7 \\
128.5 \pm 92.7 \\
33.4 \pm 29.4\end{array}$ \\
\hline $\begin{array}{l}\text { Campeche Bank (hook and line) } \\
\text { (best catch reported in 1987) }\end{array}$ & $\begin{array}{c}>60 \mathrm{yr} \\
40-59 \mathrm{yr} \\
<40 \mathrm{yr}\end{array}$ & $\begin{array}{c}14 \\
8 \\
2\end{array}$ & $\begin{array}{c}30 \\
13 \\
2\end{array}$ & $\begin{array}{c}11.3 \pm 9.4 \\
4.5 \pm 4.3 \\
2 \pm 0\end{array}$ & $\begin{array}{c}14 \\
8 \\
2\end{array}$ & $\begin{array}{c}300 \\
300 \\
86\end{array}$ & $\begin{array}{c}108 \pm 92.4 \\
159.8 \pm 79.5 \\
65.5 \pm 29\end{array}$ \\
\hline
\end{tabular}
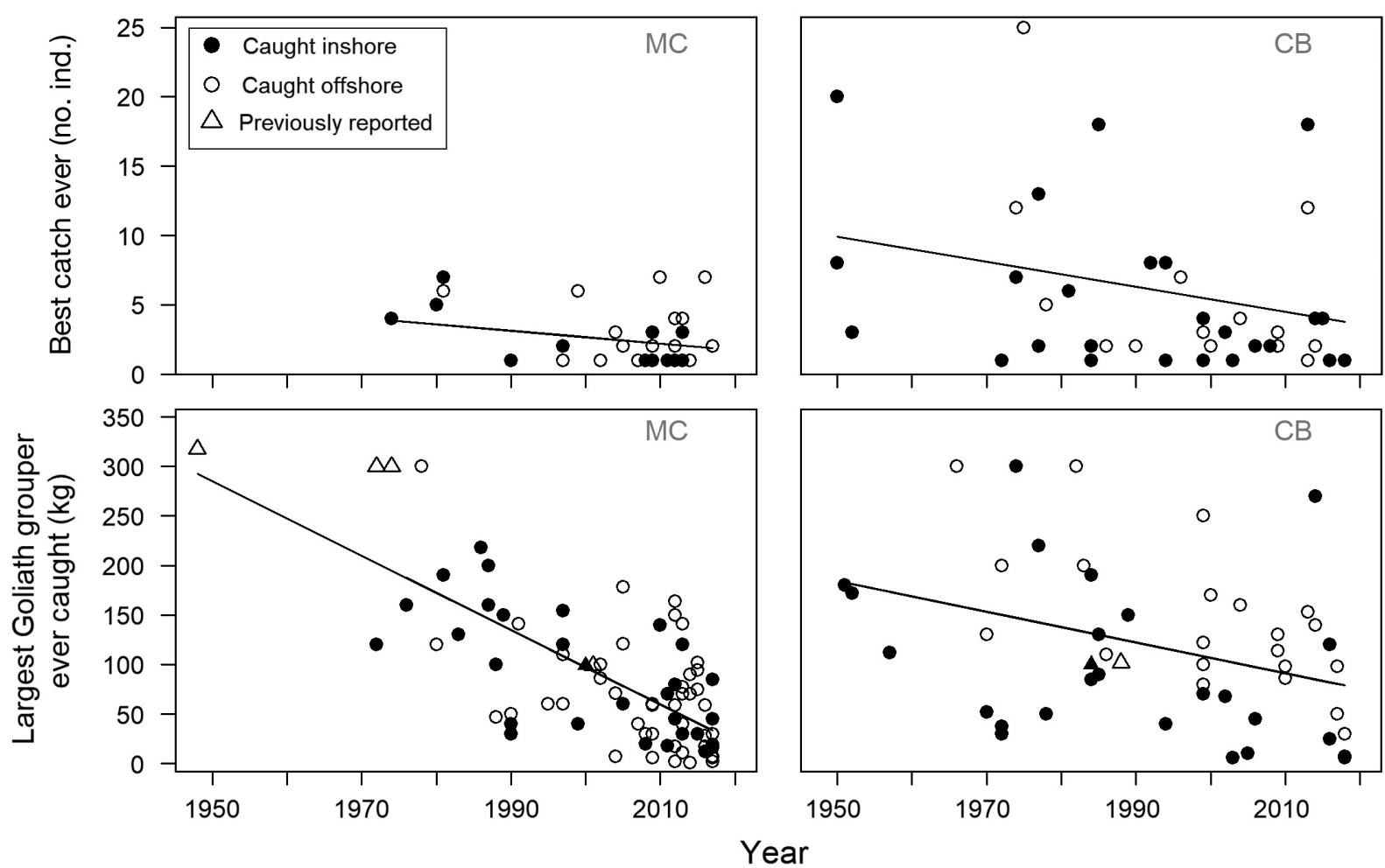

Fig. 6. The best catch (number of individuals) and size of the largest goliath grouper caught by fishers from Campeche Bank (CB) and the Mexican Caribbean (MC) as reported by our interviewees. Previously reported data are also shown (OsorioTafall 1948, Bravo 1972, 1974, Rodríguez 1984, Smith \& Flores-Granados 1988, García-Téllez 2002)

abundance is clearly remembered by veteran fishers from this region whose testimonies illustrate their LEK of fish behavior. An 84 yr old fisher pointed out, 'Their home was there (a rocky reef close to Puerto Real) ... I used to catch one (goliath grouper) ... and I left it [the fishing ground] for 15 days, 20 days, a month. Suddenly, I remembered, and I went around again, and I could fish another (goliath grouper).'

In this region, there is a strong historical tradition of fishing in rivers and coastal lagoons. Veteran fishers reported catching large goliath groupers ( $\geq 150 \mathrm{~kg})$ during the dry season in April and May inside lagoons, 
Table 3. Local ecological knowledge of fishers in the Mexican Caribbean on the past abundance and distribution of the goliath grouper Epinephelus itajara

\begin{abstract}
Fisher age and residence
Quote

\section{Past abundance}

84 yr old fisher from Chetumal

65 yr old fisher from Calderitas

54 yr old fisher from Punta Allen

47 yr old fisher from Punta Allen

'In the cenotes, there are some holes, sinkholes in the sea; that's where they [goliath groupers] are, and they go in there to eat. You go to fish there with your bait, and you hook one and take it. We fished them; there was no market.'

'In Holbox, they gave me 20 goliath groupers, like these, this size (Interviewee showing the size of the fish). Do you think that I sold them? I gave them away. There was no one to buy them.'

'To see them underwater, the most I saw was like 10 or 8 , but we would pick the big ones because some were small.'

'Commercial fishing is done out at sea; in the bay, we just go to catch goliath groupers.'

'The goliath grouper has been [used] for local consumption as well, but what happens is that because we knew where the aconchaderos ${ }^{\mathrm{a}}$ were, ... then you say 'today I want to eat goliath grouper,' and you go to that place; you dive in and there it is, a $30 \mathrm{~kg}$ goliath grouper.'
\end{abstract}

\section{Present abundance}

70 yr old fisher from Punta Allen

43 yr old fisher from Punta Allen

33 yr old individual from Tulum ${ }^{\mathrm{c}}$

30 yr old individual from Tulum ${ }^{\mathrm{c}}$

23 yr old individual from Tulum ${ }^{c}$ 'It's very, very rare to see a goliath grouper; very, very rare that you see it.'

${ }^{a}$ Rocky places that goliath groupers or other reef species use as refuge

${ }^{b}$ During the interview fishers commented this might be due to sand entering into the bay as a result of the strong hurricanes that have hit the region over the last $40 \mathrm{yr}$

${ }^{\mathrm{c}}$ Dive guide or tourism operator

'Yes, there were lots; we used to say rocky caves where the goliath grouper was found, black grouper [and] Nassau grouper would hide ... but they are not [there] any anymore. At the very end of the bay, [there] was an area with a rocky bottom and some type of aquatic vegetation, small but very pretty. There were snapper [in] big groups. Maybe the animals had to go and look for a new place because now you do not find this, and over time ... I said once 'where was the cave that was here? It has been buried; where is the vegetation? All these is gone; it is clean.' It was really very beautiful, all [of] this ... ${ }^{\text {b }}$

'The goliath grouper; it's [size and abundance are] not like [they] were. In the past, you could see them; you would say 'I'm going to a certain place to look for one,' and sure enough, you would arrive, and there would be a goliath grouper. Now, a bit of time has gone by; it is more than a year since I [last] saw one.'

'Honestly, the last goliath grouper I saw was about 8 years ago, at least since I have seen one in the sea.'

'In the past, you could see goliath groupers, other groupers [...]. Ten years ago, you could see a bit of everything [...], but now you see a reef with a few fish, and it's what you have to show to people; you cannot guarantee I am going to take you to this place, the caves, and [that] you are going to see a turtle, some octopuses, a huge goliath grouper, very pretty. Those spots are disappearing. We almost do not have any groupers here. 
1980s when finfish became the most important target species and longlines became the principal fishing gear. During the following decades, according to the fishers, about half of all individuals were captured using longlines at depths between $\sim 30-100 \mathrm{~m}$. One veteran fisher even reported the use of explosives to capture goliath groupers (Table 1). Nevertheless, even with this powerful fishing gear, goliath grouper catches did not improve over the years.

According to fishers, large individuals persisted around the bases of oil platforms, ducts, and shipwrecks. However, after 2003, fishing was prohibited around the oil platforms, which were considered to be of strategic national importance (DOF 2003). Testimony from a $56 \mathrm{yr}$ old fisher from Chiltepec reveals this when he commented, 'Here, in front of the buoys of Dos Bocas and close to the platforms out by Frontera, they [goliath groupers] were present, but you had to go close to the platforms to throw the hooks, and now they do not let you.' This perception reveals what many fishers along the coast have stated. According to fisher experience regarding the development of the oil industry in the region, the creation of these de facto exclusion zones around the oil platforms, which currently cover $853 \mathrm{~km}^{2}$, was considered to be the turning point that marked the transition to downward trends in their catches (Ramos-Muñoz et al. 2019).

Rich knowledge of the biology of this species may be extracted from interviewing different generations of fishers in Campeche Bank. According to Campeche Bank fishers, the goliath groupers in the region feed mostly on jacks Caranx spp., catfish (Ariopsis felis and Bagre marinus), mojarras (Gerreidae), little tunny Euthynnus alletteratus, and to a lesser extent, on mullet Mugil spp., minnows Cyprinella spp., pond perch Diplectrum radiale, lizardfish Synodus foetens, and goatfish Upeneus parvus. In the rivers and lagoons, goliath groupers also show an affinity for swimming crabs Callinectes spp.

In the Mexican Caribbean Sea, few people still remember the presence of this giant fish in modern times. Over the past $30 \mathrm{yr}$, there have been no captured or observed individuals that have exceeded $200 \mathrm{~kg}$ (Fig. 6, Table 2). The testimony of a $60 \mathrm{yr}$ old diving instructor who has been living in Tulum for 36 yr clearly illustrates this: 'I have heard stories about fish the size of a Volkswagen [...], but I have never seen one like that; the biggest I have seen are about 70 or 80 kilos.'

The goliath grouper in this region does not appear to have played an important role in fishing activities given its sparse presence in fishing statistics. Many of the fishers interviewed in this study mentioned that direct trade with restaurant and hotel owners increased the demand for goliath groupers as well as for their catches, illustrating the length of time that this fish was caught without being registered in official catch records. Nowadays, fishers have reported that seeing a goliath grouper is rare and that seeing a large individual goliath grouper is even rarer. Even young fishers have reported that multiple years can pass without seeing one goliath grouper underwater, as the testimony of a $33 \mathrm{yr}$ old diver from Tulum indicates, 'It is rare to see them, but they [fishers] do fish them; they are very good. Obviously, here it is the dream of a fisher to catch one.' Unlike in the Gulf of Mexico, in the Mexican Caribbean, more than $90 \%$ of the fishers interviewed in this study who caught goliath groupers did so by diving with spearguns, whereas older fishers indicated that they only used hook-and-line gears in the past. None of the respondents had observed goliath grouper spawning aggregations, but they did report seeing sites in which at least 5 individuals were fished. Fishers also reported seeing goliath groupers along the barrier reef between 10-30 m depth, specifically in the coral reefs found outside Ascension Bay and Tulum (Fig. 1).

In Chetumal Bay, fishers reported the importance of pools, which are submerged sinkholes with depths that can reach $>10 \mathrm{~m}$, as sites with relatively high goliath grouper abundance. This was clearly illustrated by the testimony of an $84 \mathrm{yr}$ old fisher from the Bay of Chetumal who said, 'There are some pools, sinkholes in the sea. That's where they [goliath groupers] are, and they go in there to eat.' In this bay, the 7 retired fishers we interviewed agreed that a population of goliath groupers was still present and that pools are key places to find these and other large fish species associated with goliath groupers, such as the bull shark Carcharhinus leucas, a combination of species that has reported to also share habitat in the Florida Keys (Frias-Torres 2006). The oldest respondent, who was 84 yr old, commented that he had heard about possible spawning aggregation sites for goliath groupers around Holbox Island, near the northern portion of the Yucatán Peninsula and Belize, despite not being able to precisely locate these places on a map. His observations agreed with those of previous studies in those sites (Craig 1966, Rubio-Cisneros et al. 2019).

In the Caribbean, $6 \%$ of the people interviewed in this study had never seen or caught a goliath grouper, but $29 \%$ of those who had caught goliath groupers had only seen immature individuals. In contrast to what the middle-aged fishers from 
Campeche bank believed, most 40-60 yr old fishers in the Mexican Caribbean believed that the goliath grouper had always been scarce (Fig. 5). From the data of the best catch ever and largest goliath grouper ever seen, we identified a reduction of at least $75 \%$ in goliath grouper abundance in the Mexican Caribbean compared to the baseline value of the 1970s (time period equivalent to 2 goliath grouper generations).

\section{DISCUSSION}

The goliath grouper, along with other species, constitutes part of the group of non-endemic fish species in the Gulf of Mexico. These species have differing conservation outcomes based on regional and global conservation assessments. Among these non-endemic species, only 8 species are more endangered locally than globally (Linardich et al. 2019). Our study shows that in the southern Gulf of Mexico and Mexican Caribbean, the status of the goliath grouper appears to agree most with the status determined via regional assessment, indicating that this species is most in danger of local extirpations (Espinosa-Perez et al. 2015). In both regions, the most common threats to this species are habitat degradation and overexploitation (Linardich et al. 2019).

The differences between the outcomes of regional and global assessments may be explained by the weight data from Florida. In this region, the goliath grouper population declined during the late 1970s and early 1980s but then increased after the implementation of a fishing moratorium in 1990. The first increases in abundance were observed in the highquality mangrove nursery of Ten Thousand Islands, and subsequent increases were observed off the central-eastern coast of Florida (Koenig et al. 2011, SEDAR47 2016). Today, the goliath grouper is no longer overfished in this region (SEDAR47 2016, Bertoncini et al. 2018).

It appears as though all Atlantic populations other than the Florida population have been seriously depleted (either legally or illegally) without showing signs of recovery. According to the latest evaluation (Bertoncini et al. 2018), the total reduction of the global population of the goliath grouper over 3 generations is $30 \%$. In contrast, the size of the local goliath grouper populations as reflected in the fishers' memories recorded in the present study may reflect a markedly greater decrease of $\geq 80 \%$ from 1970 to the present day. The trend identified from the goliath grouper capture records of Campeche Bank generally reflected the development of commercial fishing, the narrative generated from the literature, and the testimonies of fishers (Figs. 4 \& 6, Table 2). Official and historical data in the region might lead to an abundance underestimation because goliath grouper bycatch in the shrimp fishery and the catch intended for local consumption were not included. Nonetheless, the reconstruction of the regional catches in the Gulf of Mexico appears to reliably indicate that the goliath grouper fishery experienced a boom in the mid-1980s, followed by a rapid collapse that resulted in catches being close to zero until very recently.

Both the information provided by older, veteran fishers and the reconstructed catch data indicated a reduction of up to $80 \%$ of what may have been caught during the 1970s (Fig. 4, Table 2). This concurs with the information that veteran fishers shared regarding the past abundance of this species, its role as an important commercial species, and its current absence. Although it can be challenging to integrate traditional knowledge into current studies, LEK has been increasingly recognized as a valuable source of information for both species and ecosystems (Wong 2016). In our results, the knowledge from fishers was supported by the historical reconstruction of catches and the events that led to the fishery boom.

Given the magnitude of the observed reduction in catches, the goliath grouper should be considered Critically Endangered in Campeche Bank and the Mexican Caribbean, according to the IUCN criteria (UICN 2012), although it can be challenging to integrate traditional knowledge into IUCN assessments (Cross \& Cooney 2016). Currently, it is hard to find fishers who fish goliath grouper, and those who have, have mostly done so with hook-and-line gear. The records of longline catches in our study allowed us to reconstruct a broad picture of the historic drivers behind the changes in goliath grouper catch volumes, although this is not the best way to reconstruct trends given the differences in fishing gears (Fig. 6).

There are few young fishers with experience in this fishery. In informal conversations, some young fishers told us that one of the reasons that they do not fish goliath groupers is that it is less profitable than fishing shrimp. Thus, we had an unbalanced sample with which to work. For some young fishers, it was difficult to differentiate among goliath groupers and other grouper species. To minimize this confusion, we provided the fishers with photos of the different grouper species in the region. We also spoke with fishers who have had negative experiences, such as 
those stemming from a long history of negative interactions with PEMEX authorities. This has eroded the trust of some fishers in PEMEX officers.

In the Mexican Caribbean, we had trouble finding veteran fishers, particularly in Tulum. Many of the people working at sea are either national or international immigrants, for whom few data are available after what appears to have been the goliath grouper heyday. Most of the data on the largest number of goliath groupers captured in a single day were from the early 1980s in Chetumal Bay (Fig. 6). Although the data and historical records in the Mexican Caribbean are even sparser than those for Campeche Bank, misreported catches could represent an even bigger problem given the impacts that the rapidly growing tourist industry had on this species after the 1980s. The population trends appeared to be very similar between regions, with a rapid boom in the 1980s followed by a sharp decline thereafter during which this species quickly became very rare in commercial catches. In Belize, fishing mortality data suggest that the goliath grouper has also been overfished (Graham et al. 2009), and records of fishing catches showed that $99 \%$ of the individuals were immature. This resembles the history that we reconstructed for the Atlantic coast of southern Mexico.

If used as a proxy for abundance, fishing statistics indicate a reduction of more than $90 \%$ of the historical biomass found in the Mexican Caribbean in the 1980s compared with current reports (Fig. 4). This concurs with what has been conveyed by both older fishers, who recalled the historical abundance of this species, and young people working as either fishers or in the SCUBA diving industry, who believe seeing goliath groupers is rare. Our study appears to be limited by some constraints. For example, the older people we interviewed only belonged to 2 sites (i.e. Chetumal and Punta Allen). In addition, we did not visit other areas that were undoubtedly important historical places for goliath grouper catches (e.g. Cancun) that quickly became urbanized, making it difficult to locate fishers because of the high immigration rate. However, all of the evidence collected in this study suggests that the goliath grouper population of the central Mexican Caribbean appears to have been extirpated and that the Chetumal Bay pools may act as refuge sites for some individuals. Using an historical approach and IUCN criteria, the goliath grouper population of the Mexican Caribbean should also be considered Critically Endangered (UICN 2012).

There is still debate as to whether or not the goliath grouper presents protogynous hermaphroditism in the Atlantic (Bertoncini et al. 2018). However, if this species does exhibit this characteristic, the historical elimination of larger individuals may have played a key role in determining the catch trends indicated by our historical reconstruction. Our results show a progressive decrease in the presence of large individuals since the 1970s in both regions (Fig. 6, Table 2).

Historical reconstructions will never provide the mathematical elegance of either ecological monitoring or fishing statistics to assess species trajectories. However, reliable fishing statistics and ecological monitoring data are likely lacking for the major tropical regions in which the goliath grouper was originally distributed. That is, of course, the case for our study area, but it is also the case for all other regions in Central and South America. The status of vulnerable species in the tropics can be assessed by a combination of LEK and scientific knowledge, which are helpful in reconstructing the trajectories of exploitation. In many regions of the world, this type of research has helped identify decreases in the historical sizes of populations over time as well as reductions in the distributions of vulnerable fish species (GarcíaTéllez 2002, Sáenz-Arroyo et al. 2005, Gerhardinger et al. 2006, Aguilar-Perera et al. 2009, Graham et al. 2009, McClenachan 2009, Giglio et al. 2017). Our study adds to this increasing body of historical approach-based research to assess at-risk species.

The de facto refuge sites provided by the oil platforms and infrastructure offer a new avenue to understand how this species may recover in an ecosystem that has been highly modified by humans (Castello-Tickel et al. 2019). For example, in the USA and Brazil, spawning sites of several fish species have been found in highly complex reefs that are often artificial and located near estuaries and lagoons (Collins et al. 2015, Bueno et al. 2016, Giglio et al. 2016), which are habitat for resident goliath groupers (Collins 2014). In natural reefs, goliath groupers are only seen sporadically, whereas in artificial reefs, goliath groupers are present year-round and in great quantities (up to 5-fold more than in natural reefs) regardless of the depth or season (Giglio et al. 2014a, Collins et al. 2015). In both the Pacific (Schroeder \& Love 2004) and Atlantic (Friedlander et al. 2014), oil platforms have been recognized as de facto marine reserves, oases for biodiversity, and places with elevated abundance that have extended distributions of reef fish, while also being associated with the presence of large goliath groupers (Cowan \& Rose 2016, Bertoncini et al. 2018). However, no goliath groupers were reported in the only study conducted in the Mexican Caye, Cayo de Arcas, where 
there is 1 oil platform, although researchers report a great variety of marine fish associated with this human-made reef (Robertson et al. 2016). Population estimates at this platform and other platforms will be required to determine whether these human-made reefs are providing foraging or reproductive aggregation sites, which is information that is not currently available for Campeche Bank. The presence of juveniles in the Ciudad del Carmen market (Fig. 2) also suggests the presence of functional spawning sites in the vicinity.

There are still many questions that must be answered to determine the degree of connectivity among the goliath grouper subpopulations. Although both juveniles and adults show high site fidelity, they can also migrate large distances (up to $500 \mathrm{~km}$ ) to spawning sites (Pina-Amargós \& González-Sansón 2009, Koenig et al. 2011, Ellis et al. 2013, Collins et al. 2015). Given this capacity for migration, even when only a few individuals engage in the behavior, goliath groupers are likely to have wide home ranges with the potential for genetic flow between populations (Collins 2014). While genetic research is required to corroborate this hypothesis, it has been suggested that there are discrete populations in Brazil, the Caribbean, and Florida (Craig et al. 2009, Damasceno et al. 2015). In the Caribbean, the population consists mostly of juveniles (García-Téllez 2002, Graham et al. 2009) with higher growth rates than those in the northern Gulf of Mexico, which is perhaps a response to fishing pressure (Graham et al. 2009).

In the Gulf of Mexico, we still do not know if the Campeche Bank population is geographically separated from the population of the northern Gulf of Mexico. It is also unclear if the limited mangrove forest that is present in the western Gulf of Mexico could act as a biogeographic barrier to dispersal. In the state of Tamaulipas, which borders the USA, less than $25 \%$ of the coastline currently consists of mangroves, and the mangrove areas are at least 13 -fold smaller than those of Tabasco (Valderrama-Landeros et al. 2017). In contrast, the Grijalva-Usumacinta Delta, which is the most important basin system in Mesoamerica (Yáñez-Arancibia et al. 2009), still shows large mangrove forest coverage. This system and the extensive continental shelf make Campeche Bank the most productive fishing region in the Mexican portion of the Gulf of Mexico. It also remains to be determined if the goliath grouper population from this region is connected to that of the Mexican Caribbean.

There are $650 \mathrm{~km}$ of coast between the northern Mexican Caribbean and Terminos Lagoon, more than $80 \%$ of which is covered by mangroves (Valderrama-Landeros et al. 2017) and lagoons. Given that these are the primary habitats of juvenile goliath groupers (Koenig et al. 2007), it is possible that connectivity is present between the populations in this study. It is also possible that oil platforms may contribute to the recovery of the Caribbean population. Nonetheless, our results suggest that local goliath grouper populations in this study are critically endangered.

It is clear that managing the goliath grouper along with 33 other species of the Serranidae family in Mexico (INAPESCA 2018) has not resulted in adequate protection. The first step to rectify this oversight is to highlight the need to implement actions for the recovery of the goliath grouper in this region, beginning with listing this species as 'At risk of extinction' in the Mexican NOM-059SEMARNAT 2010 (DOF 2010), although it was deemed Vulnerable in its global IUCN assessment. In Brazil, the goliath grouper is listed as critically endangered (ICMBio 2018). However, its population has not been able to recover. It has been recommended that the inclusion of fishery stakeholders in management decisions, the selection of priority areas to further conservation efforts, the implementation of environmental education and population monitoring programs, and the promotion of non-destructive activities like diving tourism or catch and release sport fishing may allow populations to recover (Giglio et al. 2014b). In addition, LEK from fishers may be incorporated into fishery policies and co-management strategies (Cowie et al. 2020). Our research reiterates the importance of considering and evaluating populations of vulnerable species, such as the goliath grouper, in the correct historical context. When there are no reliable ecological or fishery data, oral history and grey literature sources with information on catches and the history of a fishery can be essential to estimating abundance and population trajectories. This type of approach may minimize the risks associated with local extirpations and the loss of genetic diversity that an at-risk species faces within its original distribution.

Acknowledgements. We thank Comunidad y Biodiversidad A.C. for the financial support to carry out this study. We also thank the fishers who agreed to be interviewed for their generous openness when speaking with us. S.F. thanks The Summit Foundation and MAR Fund for partially funding this work, and A.S.A. thanks the generous support from Cardiff University that partially funded the interviews conducted in the Mexican Caribbean. 


\section{LITERATURE CITED}

Aguilar-Perera A, González-Salas C, Tuz-Sulub A, VillegasHernández H (2009) Fishery of the goliath grouper, Epinephelus itajara (Teleostei: Epinephelidae) based on local ecological knowledge and fishery records in Yucatan, Mexico. Rev Biol Trop 57:557-566

Aguilar-Salazar F (1999) Relatos de pescadores de Quintana Roo, Vol. H. Ayuntamiento de Isla Mujeres, Ciudad de México

Aguirre A (1925) Informe que rinde al C. Presidente de la Republica el Jefe de la comisión nombrada por el mismo, para hacer estudio del Territorio Federal de Quintana Roo, Imprenta de la Dirección de Estudios Geográficos y Climatológicos. Archivo General del Estado de Quintana Roo, Fondo Revistero, Sección: Geografía. Num de revistero: R7; Num inventario: 04D11/GEO

Alcalá-Moya MG (1986) Los pescadores de la costa de Michoacán y de las lagunas costeras de Colima y Tabasco. Cuadernos de la Casa Chata, Ciudad de Mexico

Ayuntamiento-de-Campeche (1940) Listín de precios, avisos y boletines del Comité Local sobre los artículos de consumo de primera necesidad. Archivo Histórico Municipal de Campeche, Fondo H. Ayuntamiento de Campeche, Sección: Presidencia, caja 5

Babbie ER (2010) The practice of social research. Wadsworth Publishing, AltaMira Press, Walnut Creek, CA

Bertoncini AA, Aguilar-Perera A, Barreiros J, Craig MT, Ferreira BP, Koenig CC (2018) Epinephelus itajara (errata version published in 2019). The IUCN Red List of Threatened Species 2018:e.T195409A145206345. https:// dx.doi.org/10.2305/IUCN.UK.2018-2.RLTS.T195409A145 206345.en

Bravo R (1972) Isla Mujeres. Editorial Diana, Ciudad de México

Bravo R (1974) Holbox. Editorial Diana, Ciudad de México

Bueno LS, Bertoncini AA, Koenig CC, Coleman FC and others (2016) Evidence for spawning aggregations of the endangered Atlantic goliath grouper Epinephelus itajara in southern Brazil. J Fish Biol 89:876-889

Bullock LH, Murphy MD, Godcharles MF, Mitchell ME (1992) Age, growth, and reproduction of jewfish Epinephelus itajara in the eastern Gulf of Mexico. Fish Bull 90:243-249

Caldera-Noriega E (2016) El Carmen. Vision encantadora y gentil. Secretaría de Cultura del Gobierno del Estado de Camepche, Ciudad del Carmen

Carranza J (1957) Marine fisheries of the Yucatan Peninsula, Mexico. In: Proc $9^{\text {th }}$ GCFI. Gulf and Caribbean Fisheries Institute, Marathon, FL, p 144-145

Castello-Tickel S, Sáenz-Arroyo A, Milner-Gulland EJ (2019) Sunken worlds: the past and future of human-made reefs in marine conservation. Bioscience 69:725-735

Collins AB (2014) An investigation into the habitat, behavior and opportunistic feeding strategies of the protected goliath grouper (Epinephelus itajara). PhD dissertation, University of South Florida, Tampa, FL

Collins AB, Barbieri LR (2010) Behavior, habitat, and abundance of the goliath grouper, Epinephelus itajara, in the central eastern Gulf of Mexico. Fish and Wildlife Research Institute, St. Petersburg, FL

Collins AB, Motta PJ (2017) A kinematic investigation into the feeding behavior of the goliath grouper Epinephelus itajara. Environ Biol Fishes 100:309-323
Collins AB, Barbieri LR, McBride RS, McCoy ED, Motta PJ (2015) Reef relief and volume are predictors of Atlantic goliath grouper presence and abundance in the eastern Gulf of Mexico. Bull Mar Sci 91:399-418

Cowan JH, Rose KA (2016) Oil and gas platforms in the Gulf of Mexico: their relationship to fish and fisheries. In: Mikkola H (ed) Fisheries and aquaculture in the modern world. IntechOpen, Rijeka, p 95-122

Cowie W, Al Dhaheri S, Al Hashmi A, Solis-Rivera V and others (2020) IUCN guidelines for gathering of fishers' knowledge for policy development and applied use. IUCN, Gland

Craig AK (1966) Geography of fishing in British Honduras and adjacent coastal waters. Louisiana State University Press, Baton Rouge, LA

Craig MT, Graham RT, Torres RA, Hyde JR and others (2009) How many species of goliath grouper are there? Cryptic genetic divergence in a threatened marine fish and the resurrection of a geopolitical species. Endang Species Res $7: 167-174$

Cross B, Cooney R (2016) Integrating traditional knowledge into Red List assessments. Traditional Knowledge Cafe, Honolulu, HI

Dachary AC, Arnaiz Burne SM (1986) Estudios Socioeconomicos preliminares de Quintana Roo. Centro de Investigaciones de Quintana Roo, Puerto Morelos

*Damasceno JS, Siccha-Ramirez R, Morales MJA, Oliveira C and others (2015) Mitochondrial DNA evidences reflect an incipient population structure in Atlantic goliath grouper (Epinephelus itajara, Epinephelidae) in Brazil. Sci Mar 79:419-429

Delegación-de-Pesca (1985) Programa integral de desarrollo pesquero 1985-88. Delegación de pesca del Estado de Quintana Roo. Biblioteca del Archivo General de Quintana Roo. Catálogo de Documentos Técnicos. Núm. de inventario: 00355. Estante 6; Anaquel 1; Charola 3

Direccion-de-Promocion-Economica-e-Industrial-del-Estado (1970) El desarrollo de la industria pesquera en el estado de Campeche. Archivo General del Estado de Campeche, Fondo Fomento, Sección: Pesca. Serie: Discursos y ponencias; caja 19, exp. 8

DOF (Diario Oficial de la Federación) (2003) ACUERDO mediante el cual las Secretarías de Marina, de Comunicaciones y Transportes, y de Agricultura, Ganadería, Desarrollo Rural, Pesca y Alimentación, establecen medidas de seguridad en la Sonda de Campeche. Diario Oficial de la Federación. Secretaría de Marina, Ciudad de México

DOF (2010) NORMA Oficial Mexicana NOM-059-SEMARNAT-2010, Protección ambiental-Especies nativas de México de flora y fauna silvestres-Categorías de riesgo y especificaciones para su inclusión, exclusión o cambioLista de especies en riesgo. Secretaría de Medio Ambiente y Recursos Naturales, Ciudad de México

Egan D, Howell EA (eds) (2001) The historical ecology handbook: a restorationist's guide to reference ecosystems. Island Press, Washington, DC

Ellis RD, Koenig CC, Coleman FC (2013) Spawning-related movement patterns of goliath grouper (Epinephelus itajara) off the Atlantic coast of Florida. In: Proc $66^{\text {th }}$ GCFI. Gulf and Caribbean Fisheries Institute, Marathon, FL, p 395-400

Espinosa-Perez H, Carpenter KE, Sedberry G, Zapp-Sluis M, Claro R (2015) Epinephelus itajara. The IUCN Red List of Threatened Species 2015:e.T195409A70323667 https://www.iucnredlist.org/species/195409/70323667 
Ferrer G, Macías JM, Diez E, Lanz J (1928) Oceanografía en el Estado de Campeche. Periódico Oficial del Gobierno Constitucional del Estado de Campeche, Num. 4886, p 2-5

Fogerty JE (2001) Oral history: a guide to its creation and use. In: Egan D, Howell EA (eds) The historical ecology handbook: a restorationist's guide to reference ecosystems. Island Press, Washington, DC, p 101-120

Frias-Torres S (2006) Habitat use of juvenile goliath grouper Epinephelus itajara in the Florida Keys, USA. Endang Species Res 2:1-6

Friedlander AM, Ballesteros E, Fay M, Sala E (2014) Marine communities on oil platforms in Gabon, West Africa: high biodiversity oases in a low biodiversity environment. PLOS ONE 9:e103709

Fuentes D (1977) Notas sobre la situación pesquera en Quintana Roo, Dirección General del Instituto Nacional de Pesca. Subdirección de Investigaciones Tecnológicas. Biblioteca del Archivo General de Quintana Roo, Catálogo de Documentos Técnicos (tomo II). Núm de inventario: 263

Galindo-Aranda A (1967) Panorama de la situación pesquera en el estado de Campeche, Archivo General del Estado de Campeche, Fondo Fomento, Sección: Pesca. Serie: Discursos y ponencias; caja 16, exp. 1

García-Cuéllar JÁ, Arreguín-Sánchez F, Hernández Vázquez S, Lluch-Cota DB (2004) Impacto ecológico de la industria petrolera en la sonda de Campeche, México, tras tres décadas de actividad: Una revisión. Interciencia 29:311-319

García-Téllez N (2002) Situación actual de la Cherna (Epinephelus itajara, Lichtenstein 1822) en la costa de Quintana Roo, Méx., con énfasis en la bahía de Chetumal. MSc dissertation, El Colegio de la Frontera Sur, Chetumal

Gerhardinger LC, Marenzi RC, Bertoncini ÁA, Medeiros RP, Hostim-Silva M (2006) Local ecological knowledge on the goliath grouper Epinephelus itajara (Teleostei: Serranidae) in southern Brazil. Neotrop Ichthyol 4: 441-450

Gerhardinger LC, Hostim-Silva M, Medeiros RP, Matarezi J, Bertoncini ÁA, Freitas MO, Ferreira BP (2009) Fishers' resource mapping and goliath grouper Epinephelus itajara (Serranidae) conservation in Brazil. Neotrop Ichthyol 7:93-102

Giglio VJ, Adelir-Alves J, Gerhardinger LC, Grecco FC, Daros FA, Bertoncini ÁA (2014a) Habitat use and abundance of goliath grouper Epinephelus itajara in Brazil: a participative survey. Neotrop Ichthyol 12:803-810

* Giglio VJ, Bertoncini ÁA, Ferreira BP, Hostim-Silva M, Freitas MO (2014b) Landings of goliath grouper, Epinephelus itajara, in Brazil: despite prohibited over ten years, fishing continues. Nat Conserv 12:118-123

Giglio VJ, Rodrigues-Leite J, Oliveira-Freitas M, HostimSilva M (2016) Mapping goliath grouper aggregations in the southwestern Atlantic. Braz J Oceanogr 64:423-426

Giglio VJ, Bender MG, Zapelini C, Ferreira CEL (2017) The end of the line? Rapid depletion of a large-sized grouper through spearfishing in a subtropical marginal reef. Perspect Ecol Conserv 15:115-118

Götz CM (2012) Caza y pesca prehispánicas en la costa norte peninsular yucateca. Anc Mesoam 23:421-439

*Graham RT, Rhodes KL, Castellanos D (2009) Characterization of the goliath grouper Epinephelus itajara fishery of southern Belize for conservation planning. Endang Species Res 7:195-204

ICMBio (Instituto Chico Méndez de Conservación de la Biodiversidad) (2018) Livro Vermelho da Fauna Brasileira
Ameaçada de Extinção: Vol 6: Peixes. ICMBio/MMA, Brasília

INAPESCA (Instituto Nacional de Pesca y Acuacultura) (2018) ACUERDO por el que se da a conocer al actualización de la Carta Nacional Pesquera Diario Oficial de la Federación. Secretaría de Agricultura, Ganadería, Desarrollo Rural, Pesca y Alimentación, Ciudad de México

INEGI (Instituto Nacional de Estadística y Geografía) (1943) Estados Unidos Mexicanos. 6to Censo de Población 1940. Secretaría de la Economía Nacional, Dirección General de Estadística, Mexico City

INEGI (2017) Conjunto de datos vectoriales de la carta de Uso del suelo y vegetacion serie VI. Conjunto Nacional. Instituto Nacional de Estadistica y Geografia, Mexico City

IUCN (2012) IUCN Red List categories and criteria: version 3.1. IUCN, Gland. www.iucnredlist.org/resources/ categories-and-criteria

Jiménez-Cano NG (2017) Ictioarqueología del Mundo Maya: evaluando la pesca prehispánica (250-1550 d.C) de las Tierras Bajas del Norte. PhD thesis, Universidad Autónoma de Madrid

* Jiménez Cano NG, Sierra-Sosa TN (2018) Pesquerías en un asentamiento costero maya del período clásico: análisis ictioarqueológicos en Xcambó (Yucatán, México). Antípoda Revista de Antropología y Arqueología 31: $25-44$

Koenig CC, Coleman FC, Eklund AM, Schull J, Ueland J (2007) Mangoves as essential nursery habitat for goliath grouper (Epinephelus itajara). Bull Mar Sci 80:567-586

*Koenig CC, Coleman FC, Kingon K (2011) Pattern of recovery of the goliath grouper Epinephelus itajara population in the southeastern US. Bull Mar Sci 87:891-911

* Linardich C, Ralph GM, Robertson DR, Harwell H, Polidoro BA, Lindeman KC, Carpenter KE (2019) Extinction risk and conservation of marine bony shorefishes of the Greater Caribbean and Gulf of Mexico. Aquat Conserv 29:85-101

Marín-Guardado G (2000) Holbox: antropología de la pesca en una isla del Caribe mexicano. Zamora, Michoacán

Martinez-Martinez ST, Gonzalez-Laxe F (2016) La construccion de la politica pesquera en Mexico. Una mirada desde el campo geografico. Atl Rev Econ 2:1-27

*McClenachan L (2009) Historical declines of goliath grouper populations in South Florida, USA. Endang Species Res 7:175-181

McClenachan L, Cooper AB (2008) Extinction rate, historical population structure and ecological role of the Caribbean monk seal. Proc R Soc B 275:1351-1358

McClenachan L, Ferretti F, Baum JK (2012) From archives to conservation: why historical data are needed to set baselines for marine animals and ecosystems. Conserv Lett 5: 249-259

Morelet A, Squier MF (1871) Travels in Central America: including accounts of some regions unexplored since the conquest. Trübner, London

Osorio-Tafall BF (1948) Posibilidades de la industria pesquera-conservera en el Territorio de Quintana Roo, Gobierno del Territorio de Quintana Roo. Archivo General del Estado de Quintana Roo, Fondo Federación de Cooperativas, Sección: Consejo de administración, Caja 4, exp. 148

Peña MTdl, Ibarra DS (1942) Campeche económico. T. 2. Gobierno Constitucional del Estado de Campeche, Campeche 
Pérez-Chan A (1970) Edición especial por la visita de Luis Echeverria Renovación (semanario) Núm 669. Frontera, Tabasco

*Pina-Amargós F, González-Sansón G (2009) Movement patterns of goliath grouper Epinephelus itajara around southeast Cuba: implications for conservation. Endang Species Res 7:243-247

Ramírez-Rodríguez M (2015) La pesquería de camarón en Campeche: Desarrollo histórico y perspectiva. Cienc Pesq 23:73-87

Ramos-Muñoz DE, Ramos-Reyes R, Zamora-Cornelio LF, Hernández-De la Cruz A, Espinoza-Tenorio A (2019) Exclusión en el Golfo de México: una visión desde los pescadores sobre la industria petrolera en Tabasco. Rev Colomb Geogr 28:357-372

Rhodes KL, Graham RT (2009) Range-wide status and conservation of the goliath grouper Epinephelus itajara: introduction. Endang Species Res 7:163-165

Robertson DR, Perez-España H, Nuñez Lara E, Puc Itza F, Simões N (2016) The fishes of Cayo Arcas (Campeche Bank, Gulf of Mexico): an updated checklist. ZooKeys 640:139-155

Rodríguez R (1984) Los pescadores de la Laguna de Términos. Cuadernos de la Casa Chata, Ciudad de México

* Rubio-Cisneros NT, Moreno-Báez M, Glover J, Rissolo D and others (2019) Poor fisheries data, many fishers, and increasing tourism development: interdisciplinary views on past and current small-scale fisheries exploitation on Holbox Island. Mar Policy 100:8-20

Sadovy Y, Eklund AM (1999) Synopsis of biological data on the Nassau grouper, Epinephelus striatus (Bloch, 1792), and the jewfish, E. itajara (Lichtenstein, 1822). NOAA Tech Rep NMFS 146

Sáenz-Arroyo A, Revollo-Fernández D (2016) Local ecological knowledge concurs with fishing statistics: an example from the abalone fishery in Baja California, Mexico. Mar Policy 71:217-221

Sáenz-Arroyo A, Roberts CM, Torre J, Cariño-Olvera M (2005) Using fishers' anecdotes, naturalists' observations and grey literature to reassess marine species at risk: the case of the Gulf grouper in the Gulf of California, Mexico. Fish Fish 6:121-133

Sáenz-Arroyo A, Roberts CM, Torre J, Cariño-Olvera M, Hawkins JP (2006) The value of evidence about past abundance: marine fauna of the Gulf of California through the eyes of $16^{\text {th }}$ to $19^{\text {th }}$ century travellers. Fish Fish 7:128-146

'Santiago J, Baro A, (1992) Mexico's giant fields, 1978-1988 decade. In: Halbouty MT (ed) Giant oil and gas fields of the decade 1978-1988. American Association of Petroleum Geologists
Schroeder DM, Love MS (2004) Ecological and political issues surrounding decommissioning of offshore oil facilities in the Southern California Bight. Ocean Coast Manage 47:21-48

SEDAR47 (Southeast Data, Assessment, and Review) (2016) Stock assessment report for goliath grouper of the South Atlantic and Gulf of Mexico. Florida Fish and Wildlife Conservation Commission Fish and Wildlife Research Institute, St. Petersburg, FL

Smith MK, Flores-Granados F (1988) Contribución al conocimiento de la pesquería de escama en el sureste del golfo de México por embarcaciones de arrastre con capacidad de 200 toneladas. In: Carmen CRIP- (ed) Boletín Informativo. Secretaría de Pesca, Cd. del Carmen, Campeche, p 1-20

Smith MK, Peña-Durán LF, Zamora JA, Borges-Cervantes H, Echavarría-Vera F (1988) Contribución al conocimiento de la captura comercial de la región costera CampecheTabasco: Especies, temporadas, reclutamiento y reproducción. In: Carmen CRIP- (ed) Boletín Informativo. Secretaría de Pesca, Cd. del Carmen, Campeche, p 21-50

Solís-Ramírez MJ (1966) Recursos pesqueros del Territorio de Quintana Roo, Mexico Instituto Nacional de Investigaciones Biológico-Pesqueras

Tello-Domínguez M (1988) Las instituciones y la pesca en Tabasco. Villahermosa, Tabasco

Tudela F (1989) La modernización forzada del trópico: El caso de Tabasco. Centro de Investigación y Estudios Avanzados del Instituto Politécnico Nacional I Federación Internacional de Institutos de Estudios Avanzados I Instituto de Investigaciones de las Naciones Unidas para el Desarrollo Social I El Colegio de México A.C., México

Valderrama-Landeros LH, Rodriguez-Zuñiga MT, TrocheSouza C, Velazquez-Salazar S, and others (2017) Manglares de México: actualizacion y exploracion de los datos del sistema de monitoreo 1970/1980-2015. Comision Nacional para el Conocimiento y Uso de la Biodiversidad, Ciudad de Mexico

Wong P (2016) Traditional ecological knowledge and practice and Red List assessments: guidelines and considerations for integration. IUCN, Washington, DC

*Yáñez-Arancibia A, Day JW, Currie-Alder B (2009) Functioning of the Grijalva-Usumacinta River Delta, Mexico: challenges for coastal management. Ocean Yearb Online 23:473-501

Zapelini C, Giglio VJ, Carvalho RC, Bender MG, Gerhardinger LC (2017) Assessing fishing experts' knowledge to improve conservation strategies for an endangered grouper in the southwestern Atlantic. J Ethnobiol 37: 478-493 
Appendix. Interview

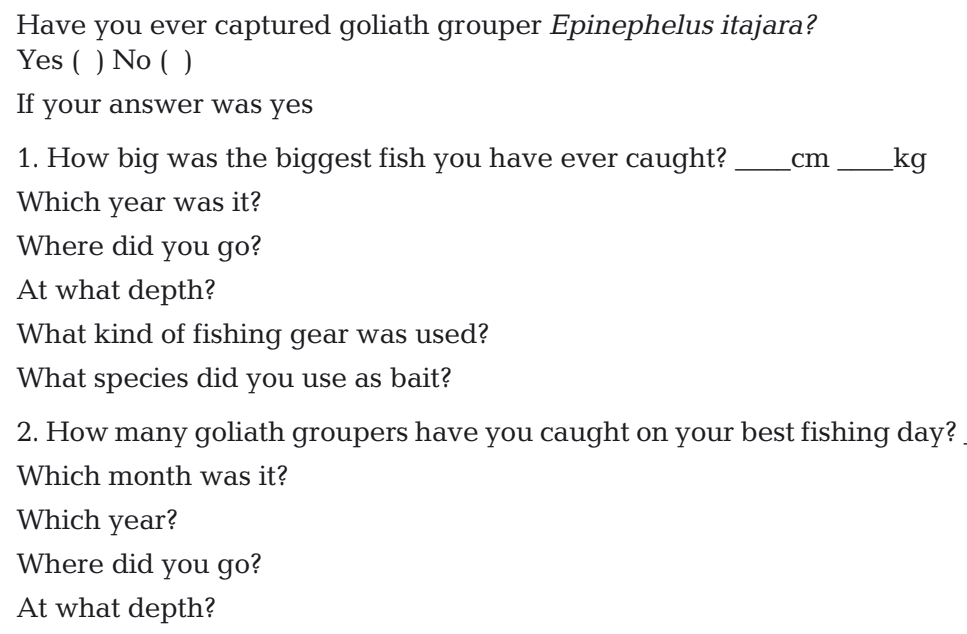

Editorial responsibility: Uwe Krumme, Rostock, Germany Reviewed by: 3 anonymous referees
Submitted: May 1, 2020

Accepted: May 21, 2021

Proofs received from author(s): August 8, 2021 